\title{
PENINGKATAN KETERAMPILAN MEMPRODUKSI TEKS EKSPOSISI SECARA LISAN DENGAN POLA KOLABORATIF THINK PAIR SHARE MELALUI MEDIA VIDEO PADA PESERTA DIDIK KELAS X IPA1 SMAN 2 BANYUASIN 1
}

\author{
Yusnah $^{1}$, Missriani $^{2}$, Dessy Wardiah ${ }^{3}$ \\ vusnah303@gmail.com ${ }^{1}$ missriani05@yahoo.com², dessywardiah77@ gmail.com ${ }^{3}$ \\ Mahasiswa Pascasarjana Universitas PGRI Palembang
}

\begin{abstract}
Abstrak: Penelitian ini bertujuan untuk meningkatkan keterampilan memproduksi teks eksposisi secara lisan dengan pola kolaboratif think pair share melalui media video pada peserta didik kelas X IPA 1 SMAN 2 Banyuasin 1. Penelitian ini untuk mengukur tingkat keberhasilan memproduksi teks eksposisi secara lisan dengan pola kolaboratif think pair share melalui video diadakan tes evaluasi disetiap siklus yang dilakukan. Pada siklus I nilai rata-rata keaktifan siswa 50,\%, pada siklus II nilai rata-rata keaktifan siswa mencapai $90 \%$, artinya nilai keaktifan siswa mengalami peningkatan sebesar $40 \%$. Selanjutnya nilai kemampuan perserta didik dalam memproduksi teks eksposisi secara lisan dengan pola kolaboratif think pair share melalui media video. pada siklus I baru mencapai $62,33 \%$ setelah diadakan tindakan pada siklus II nilai rata-rata keterampilan memproduksi teks ekspsisi secara lisan dengan pola kolaboratif think pair share melalui media video mencapai 76,83\%. Jadi ada peningkatan sebesar $14,50 \%$. Berdasarkan nilai tersebut maka dapat disimpulkan bahwa pola kolaboratif think pair share melalui media vidio mampu meningkatkan keterampilan memproduksi teks eksposisi secara lisan pada peserta didik kelas X IPA1 SMAN2 Banyuasin 1.
\end{abstract}

Kata kunci: Memproduksi Teks Eksposisi, Pola kolaboratif Think pair Share, Media Video.

\begin{abstract}
This study aims to improve the skills of producing oral exposition text with collaborative patterns of think pair share through video media on students of class X IPA 1 of SMAN 2 Banyuasin 1. This research is to measure the success rate of producing oral exposition text with collaborative patterns of think pair share through video held evaluation tests in each cycle conducted. In the first cycle the average value of student activeness of 50,\%, in the second cycle the average value of student activity reached $90 \%$, meaning that the value of student activity has increased by $40 \%$. Furthermore, the value of the ability of students in producing oral exposition text with collaborative patterns of think pair share through video media. in the first cycle, it only reached $62.33 \%$ after taking action in the second cycle, the average value of skills in producing verbal excision texts with collaborative patterns of think pair share through video media reached $76.83 \%$. So there is an increase of $14.50 \%$. Based on this value, it can be concluded that the collaborative pattern of think pair share through video media can improve the skills of producing oral exposition texts in class X IPA1 students of SMAN2 Banyuasin 1.
\end{abstract}

Keywords: Producing Exposition Text, Collaborative Patterns of Think Pair Share, Video Media. 


\section{PENDAHULUAN}

Menurut pendapat Tarigan (2015;3), berbicara adalah suatu keterampilan berbahasa yang berkembang pada kehidupan anak, yang hanya didahului oleh keterampilan menyimak, dan pada masa tersebutlah kemampuan berbicara atau berujar dipelajari. Berbicara sudah barang tentu berhubungan erat dengan perkembangan kosa kata yang diperoleh oleh sang anak; melalui kegiatan menyimak dan membaca.

Hal ini dipertegas oleh Saddhono (2014:54), yang menyatakan bahwa berbicara lebih daripada sekadar sarana pengucapan bunyi-bunyi atau kata-kata. Berbicara adalah cara untuk mengomunikasikan gagasan-gagasan yang disusun serta dikembangkan sesuai dengan kebutuhan pendengar atau penyimak. Keterampilan berbahasa sangat penting untuk dikuasai. Berbicara sebagai suatu keterampilan berbahasa diperlukan untuk berbagai keperluan. Sewaktu-waktu keterampilan berbicara dibutuhkan untuk dapat menyampaikan informasi kepada siapa saja dengan baik. Oleh sebab itu, pembelajaran berbicara harus dibelajarkan dengan sebaik mungkin yang tertuang dalam kurikulum.

\section{Bergantinya Kurikulum Tingkat} Satuan Pendidikan (KTSP) menjadi Kurikulum 2013 sedikit banyak memunculkan kebingungan di kalangan guru dan peserta didik. Perubahan yang terkesan mendadak dan dipaksakan menimbulkan masalah baru dalam dunia pendidikan. Walaupun disisi lain Kurikulum 2013 juga memberikan solusi terhadap aspek pendidikan karakter bangsa Indonesia.

Salah satu masalah yang muncul diakibatkan bergantinya Kurikulum Tingkat Satuan Pendidikan (KTSP) menjadi Kurikulum 2013 terdapat pada mata pelajaran bahasa Indonesia. Pada mata pelajaran bahasa Indonesia, materi yang terdapat di dalam Kurikulum Tingkat Satuan Pendidikan (KTSP) sebagian besar berubah jika dibandingkan dengan Kurikulum 2013. Pada Kurikulum Tingkat Satuan Pendidikan (KTSP), pembelajaran bahasa Indonesia berbasis pada empat kemampuan berbahasa, yaitu mendengar, menyimak, menulis, dan berbicara. Namun, pada Kurikulum 2013 pembelajaran bahasa Indonesia berbasis pada teks. Lima teks dasar, yaitu narasi, eksposisi, persuasi, argumentasi, dan deskripsi, kini berubah menjadi beberapa teks baru. Di antaranya, yaitu teks anekdot, negosiasi, laporan hasi observasi, dan lain-lain.

Standar Isi Kurikulum 2013 terdapat empat Kompetensi Inti (KI), yaitu sikap religius, sikap sosial, pengetahuan, dan keterampilan. Setiap Kompetensi Inti tersebut terdapat 
beberapa Kompotensi Dasar (KD).

Khusus pada Kompetensi Dasar pengetahuan dan keterampilan, didalamnya terdapat beberapa jenis teks baru yang telah disebutkan.Teks-teks tersebut merupakan bahan ajar yang perlu dibelajarkan kepada peserta didik. Terdapat beberapa kegiatan dalam Kompetensi Dasar (KD) tersebut, yaitu memahami, mengonversi, meringkas, memproduksi, dan lain-lain. Kegiatan itulah yang menjadi Kompetensi Dasar (KD) atau hal yang harus dikuasi oleh peserta didik. Beberapa kegiatan tersebut selalu diwujudkan baik melalui lisan maupun tulisan. Salah satu teks yang terdapat pada kurikulum 2013, yaitu teks eksposisi.

Teks eksposisi berasal dari kata ekspos yang berarti, memberikan disertai dengan analisis dan penjelasan. Adapun sebagai suatu teks, eksposisi dapat diartikan sebagai karangan yang menyampaikan argumentasi dengan tujuan untuk meyakinkan orang lain. Dalam pengembangan teks eksposisi dapat menggunakan fakta, contohcontoh, gagasan-gagasan penulisnya ataupun pendapat-pendapat para ahli. (Kosasih 2017:23-24).

Salah satu faktor penyebab rendahnya kemampuan siswa dalam memproduksi teks eksposisi secara lisan pada peserta didik di SMAN 2 Banyuasin 1 adalah jarang menggunakan bahasa Indonesian dalam intraksi keseharian.

Dalam praktek komunikasi diluar kelas, siswa SMAN 2 Banyuasin 1 lebih sering menggunakan bahasa daerah yaitu bahasa Palembang dan bahasa Jawa.

$\begin{array}{lrr}\text { Banyak } & \text { faktor } & \text { yang } \\ \text { menyebabkan } & \text { kurangnya } & \text { nilai } \\ \text { kemampuan } & \text { peserta didik } & \text { sekolah }\end{array}$
SMAN 2 khusunya kelas X IPA 1 dalam memproduksi teks eksposisi secara lisan. Terdapat dua faktor besar yang mempengaruhi, yaitu faktor internal dan faktor eksternal. Faktor internal yang mempengaruhi kurangnya kemampuan memproduksi teks eksposisi secara lisan, yaitu minat dan rasa bosan yang melanda peserta didik saat melakukan pembelajaran.

Pengaruh faktor eksternal salah satunya yaitu faktor lingkungan yang kurang mendukung. Keseharian peserta didik lebih banyak menggunakan bahasa daerah atau Jawa selain bahasa Indonesia, seperti bahasa Palembang maupun Jawa. Seringnya penggunaan bahasa daerah selain bahasa Indonesia berimbas pada keterampilan peserta didik dalam memproduksi teks eksposisi secara lisan dalam pembelajaran. Peserta didik sering menggunakan bahasa sehari-hari dalam pembelajaran. Konstruksi kalimatnya pun terkadang sesuai dengan bahasa selain bahasa Indonesia. Oleh sebab itu, 
nilai keterampikan memproduksi teks eksposisi secara lisan peserta didik masih kurang.

Upaya yang dilakukan peneliti untuk meningkatkan ketercapaian peserta didik Sekolah SMAN 2 khususnya kelas $\mathrm{X}$ IPA 1 dalam pembelajaran memproduksi teks eksposisi secara lisan, peneliti menggunakan pola kolaboratif. John Myers (dalam Ruhcitra 2008) merujuk pada kamus untuk menjelaskan definisi collaboration yang berasal dari akar kata Latin dengan makna yang menitik beratkan proses kerjasama. Ted Panitz (dalam Ruhcitra 2008) menjelaskan bahwa pembelajaran pola kolaboratif adalah suatu filsafat personal, bukan sekadar teknik pembelajaran dikelas. Menurutnya, kolaborasi adalah filsafat interaksi dan gaya hidup yang menjadikan kerjasama sebagai suatu struktur interaksi yang dirancang sedemikian rupa guna memudahkan usaha kolektif untuk mencapai tujuan bersama.

\section{METODE PENELITIAN}

Penelitian ini Menggunakan Penelitian Tindakan (PT). Menurut Uno (2014: 12) Penelitian Tindakan merupakan yang dilakukan di Kelas memang memiliki dan karakteristik tertentu. Dengan kata lain penelitian tindakan adalah penelitian yang sifatnya langsung memberikan tindakan kuratif (masalah) yang dihadapi dalam proses pembelajaran. Penelitian Tindakan (PT) suatu refleksi diri kolektif yang dilakukan oleh peserta-pesertanya dalam situasi sosial untuk meningkatkan penalaran dan praktik sosial Kemmis dan Mc Taggart (dalam Daryanto 2014:3).

Berdasarkan berdasarkan pengertian tersebut, dapat disimpulakan bahwa Penelitian Tindakan adalah penelitian dilakukan oleh seorang guru atau peneliti, sehingga hasil belajar peserta didik menjadi meningkat dan lebih baik. Penelitian Tindakan (PT) termasuk Penelitian Kualitatif walaupun data yang dikumpulkan bisa saja bersifat kuantitatif (Ekawarna 2011:5).

\section{PEMBAHASAN}

Berdasarkan penelitian pada
proses pembelajaran yang telah
dilaksanakan beberapa siklus, maka
dalam melaksanakan pembelajaran memproduksi teks eksposisi secara lisan dengan menggunakan pola kolaboratif think pair share melalui video pada siswa kelas X SMAN 2 Banyuasin 1 hasilnya akan dibahas pada penjelasan berikut ini.

\section{Pembahasan Siklus I}

Hasil tindakan siklus I yang dilaksanakan hari Senin, 24 Februari 2020 dan hari Selasa, 16 Maret 2020 menunjukkan bahwa nilai presentase keaktifan siswa masih rendah, yaitu 
hanya $50 \%$ atau 15 siswa dengan kategori berhasil, sedangkan siswa yang berkategori cukup mencapai 8 siswa dengan presentase $26,67 \%$, sedangkan siswa yang berkategori kurang sejumlah 7 siswa atau 23,33\%. Dengan demikian keaktifan siswa perlu ditingkatkan.

Berdasarkan hasil observasi dapat dideskripsikan bahwa siswa dalam berdiskusi kurang aktif. Sebagian besar siswa kurang berani menyampaikan pendapat dan beinteraksi dengan teman lainnya. Siswa juga tidak berani mengambil keputusan serta kurang berani mengomentari anggota kelompok lain yang mempresentasikan hasil diskusinya. Hal ini terjadi karena selama ini siswa kurang terlatih dalam pembelajaran memproduksi teks eksposisi secara lisan. Di samping itu, siswa juga merasa terganggu adanya observer yang mengamati sikapnya. Siswa merasa canggung dan malu. Siswa terlihat bingung dengan pola kolaboratif think paiar share melalui video. Sebagian siswa masih butuh bimbingan.

Hasil observasi yang dilakukan oleh teman sejawat terhadap guru/peneliti selama proses pembelajaran adalah proses pembelajaran guru/peneliti berkategori baik. Artinya guru/peneliti mempunyai kemampuan atau kompetensi yang baik dalam mengajar dan mengelola kelas. Namun apakah kemampuan guru ini akan stabil atau meningkat, maka penilaian terhadap kemampuan guru akan dilakukan pada siklus berikutnya.

Berdasarkan hasil pengolahan data pada tabel 4.3 nilai rata-rata tes kemampuan memproduksi teks eksposisi secara lisan dengan pola kolaboratif think pair share melalui media video pada peserta didik kelas X IPA1 SMAN 2 Banyuasin 1 pada tindakan siklus I hanya 14 siswa yang nilainya mencapai KKM atau sekitar $(46,67 \%)$ dari jumlah 30 siswa. Sedangkan nilai rata-rata mencapai $62,33 \%$ artinya adalah memproduksi teks eksposisi secara lisan kemampuan siswa masih rendah. Sedangkan 16 siswa lainnya masih di bawah KKM, artinya pada siklus I ini belum tuntas, karena kriteria keberhasilan siswa adalah 85\% siswa mencapai KKM atau 26 siswa. Dilihat daari tindakan siklus I ini masih banyak yang harus diperhatikan oleh peneliti untuk mencapai kriteria keberhasilan yang telah ditentukan.

\section{Pembahasan Siklus II}

Pelaksanaan siklus II ini dilakukan pada hari Senin, 20 April 2020 dan Selasa, 05 Mei 2020. Berdasarkan hasil pengolahan data observasi siswa yang ditunjukkan pada tabel 4.4 menunjukkan bahwa tingkat keaktifan siswa memproduksi teks eksposisi menunjukkan tingkat keaktifan yang lebih baik. Berdasarkan pengamatan dari lima aspek yang 
diamati semuanya mengalami peningkatan dari siklus sebelumnya. Dari siklus I nilai rata-rata keaktifan siswa 56,99\% pada siklus II, pada siklus II nilai rata-rata keaktifan siswa mencapai 85,23\%. Artinya nilai keaktifan siswa mengalami peningkatan $28,24 \%$.

Membahas tentang hasil analisis pada observasi kegiatan guru yang terdapat pada tabel 4.5 nilai observasi guru/peneliti pada tindakan siklus II juga mengalami kenaikkan. Berdasarkan hasil analisis data tersebut memperkuat asumsi peneliti bahwa penyebab rendahnya kemampuan siswa dalam memproduksi teks eksposisi secara lisan bukan disebabkan oleh ketidakmampuan guru dalam mengajar dan mengelola kelas. Dalam dua kali pembelajaran nilai kemampuan guru sangat bagus.

Berdasarkan hasil analisis kemampuan siswa dalam memproduksi teks eksposisi secara lisan pada tindakan II mengalami peningkatan yang signifikan. Jika pada siklus I nilai ratarata siswa $62,33 \%$ maka pada siklus II ini mengalami peningkatan menjadi $76,83 \%$ jadi mengalami peningkatan sejumlah 14,5. Siswa yang berhasil mencapai nilai (Kriteria Ketuntasan Minimal (KKM) pada siklus sejumlah 14 siswa atau $(46,67 \%)$ pada siklus II mengalami peningkatan sejumlah 27 siswa atau $(90,00 \%)$. Berdasarkan hasil analisis tersebut maka ada peningkatan sejumlah (43,33\%). Berdasarkan analisis data nilai kemampuan memproduksi teks eksposisi secara lisan dengan menggunakan pola kolaboratif think pair share melalui video telah mencapai kriteria keberhasilan yang ditentukan, yaitu nilai kemampuan siswa memproduksi teks eksposisi rata-rata 70 dan siswa yang mencapai (Kriteria Ketuntasan Minimal (KKM) sejumlah $85 \%$ atau 26 siswa. Pada akhir pembelajaran siklus II ini telah mencapai (90\%) atau 27 siswa. Jadi hanya 3 siswa yang belum bisa mencapai nilai (Kriteria Ketuntasan Minimal (KKM).

Berdasarkan analisis hasil tindakan yang dilaksanakan selama 2 siklus maka telah diperoleh hasil yang menunjukkan keberhasilan, oleh sebab itu penelitian tindakan kelas menggunakan pola kolaboratif think pair share melalui video akan dihentikan dan dapat disimpulkan bahwa penelitian dengan judul peningkatan keterampilan memproduksi teks eksposisi secara lisan dengan Pola Kolaboratif Think Pair Share melalui media video pada perserta didik Kelas X IPA1 SMAN 2 Banyuasin 1 dinyatakan berhasil.

3. Rekapitulasi Nilai Observasi dan Nilai Memproduksi teks eksposisi.

- Rekapitulasi Nilai Observasi Agar pembaca dapat paham tentang hasil-hasil yang diperoleh dari lembar observasi tingkat keaktifan siswa 
dalam mengikuti proses pembelajaran memproduksi teks eksposisi secara lisan maka dibuat rekapitulasi nilai observasi dan nilai-nilai kemampuan memproduksi teks eksposisi secara lisan. Dibawah ini akan di gambarkan tabelnya.

\section{REKAPITULASI NILAI RATA-RATA OBSERVASI KEAKTIFAN SISWA MEMPRODUKSI TEKS EKSPOSISI KELAS X SMAN 2 BANYUASIN 1}

\begin{tabular}{|c|c|c|c|}
\hline \multirow[t]{2}{*}{ NO } & \multirow[t]{2}{*}{ Nama Siswa } & \multicolumn{2}{|c|}{ Hasil Tindakan Persiklus } \\
\hline & & Siklus I & Siklus II \\
\hline 1 & $\mathrm{AB}$ & 60 & 80 \\
\hline 2 & $\mathrm{AD}$ & 60 & 60 \\
\hline 3 & AT & 40 & 85 \\
\hline 4 & $\mathrm{AM}$ & 75 & 85 \\
\hline 5 & $\mathrm{AR}$ & 75 & 85 \\
\hline 6 & AN & 35 & 90 \\
\hline 7 & AY & 45 & 80 \\
\hline 8 & DK & 65 & 65 \\
\hline 9 & $\mathrm{DN}$ & 70 & 65 \\
\hline 10 & ES & 70 & 70 \\
\hline 11 & EL & 70 & 75 \\
\hline 12 & FJ & 35 & 75 \\
\hline 13 & JK & 65 & 80 \\
\hline 14 & JT & 75 & 70 \\
\hline 15 & LM & 70 & 75 \\
\hline 16 & MF & 75 & 75 \\
\hline 17 & MY & 55 & 85 \\
\hline 18 & MD & 70 & 95 \\
\hline 19 & MS & 70 & 90 \\
\hline 20 & ND & 55 & 90 \\
\hline 21 & NK & 70 & 95 \\
\hline 22 & NM & 55 & 95 \\
\hline 23 & $\mathrm{RN}$ & 70 & 95 \\
\hline 24 & SN & 75 & 65 \\
\hline 25 & ST & 45 & 85 \\
\hline 26 & SR & 70 & 95 \\
\hline
\end{tabular}




\begin{tabular}{|l|l|c|c|}
\hline 27 & TS & 50 & 95 \\
\hline 28 & TT & 40 & 95 \\
\hline 29 & WL & 70 & 95 \\
\hline 30 & WY & 40 & 95 \\
\hline \multicolumn{2}{|l|}{ Jumlah Nilai } & 1.720 & 2.560 \\
\hline $\begin{array}{l}\text { Rata-rata Keaktifan } \\
\text { siswa }\end{array}$ & 57,90 & 85.83 \\
\hline \multicolumn{2}{|l|}{ Jumlah Siswa Aktif } \\
\hline \multicolumn{2}{|l|}{ Presentase Keaktifan } & 15 & 27 \\
\hline
\end{tabular}

Sumber ( Arikunto 2014)

Berdasarkan hasil siklus I menunjukan bahwa nilai persentase observasi keaktifan siswa masih rendah, yaitu hanya $50 \%$ atau 15 siswa dengan ketegori berhasil, dan siklus II menunjukan bahwa nilai persentase observasi keaktifan siswa meningkat $85,83 \%$ atau 27 siswa dengan kategori berhasil jadi kesimpulannya ada peningkatan dilihat dari siklus I dan siklus II.

\section{REKAPITULASI NILAI RATA-RATA PER SIKLUS KEAKTIFAN MEMPRODUKSI TEKS EKSPOSISI SECARA LISAN SISWA KELAS X IPA1 SMAN 2 BANYUASIN 1}

\begin{tabular}{|c|c|c|c|c|c|}
\hline No & \multicolumn{5}{|c|}{ Aspek Pengamatan } \\
\hline & $\begin{array}{l}\text { Memberik } \\
\text { an } \\
\text { Pendapat }\end{array}$ & $\begin{array}{l}\text { Memberikan } \\
\text { Menanggapi }\end{array}$ & $\begin{array}{l}\text { Mengerjak } \\
\text { an tugas } \\
\text { yang } \\
\text { diberikan }\end{array}$ & $\begin{array}{l}\text { Memotivasi } \\
\text { dalam } \\
\text { menger jakan } \\
\text { tugas }\end{array}$ & $\begin{array}{l}\text { Toleransi } \\
\text { menerima } \\
\text { pendapat } \\
\text { kelompok }\end{array}$ \\
\hline $\mathbf{1}$ & \multicolumn{5}{|c|}{ Tindankan Siklus I } \\
\hline & $52,50 \%$ & $56,66 \%$ & $60,83 \%$ & $60,33 \%$ & $59,16 \%$ \\
\hline $\mathbf{2}$ & \multicolumn{5}{|c|}{ Tindakan Siklus II } \\
\hline & $85,00 \%$ & $82,50 \%$ & $85,00 \%$ & $88,33 \%$ & $85,23 \%$ \\
\hline
\end{tabular}

Berdasarkan pertemuan II siklus I hasil rekapitulasi keaktifan keaktifan siawa dari setiap aspek maka dapat disimpulkan bahwa keberanian siswa berpendapat untuk memecahkan masalah sejumlah 52,50\%, kemudian keberanian siswa menanggapi pendapat orang lain sejumlah $56,66 \%$, keaktifan 
siswa mengerjakan tugas dengan baik sejumlah $60,83 \%$ dan keaktifan siswa mampu memotivasi tugas-tugas adalah $60,33 \%$, dan siswa yang mau menerima pendapat teman ada $59,16 \%$.

Berdasarkan pertemuan II siklus II hasil rekapitulasi keaktifan siawa dari setiap aspek maka dapat disimpulkan bahwa keberanian siswa berpendapat untuk memecahkan masalah sejumlah
$85,00 \%$, kemudian keberanian siswa menanggapi pendapat orang lain sejumlah 82,50\%, keaktifan siswa mengerjakan tugas dengan baik sejumlah $85,00 \%$ dan keaktifan siswa mampu memotivasi tugas-tugas adalah $88,33 \%$, dan siswa yang mau menerima pendapat teman ada $85,23 \%$, jadi kesimpulannya dilihat dari siklus I dan siklus II ada peningkatan.

\section{PRESENTASE PENINGKATAN NILAI OBSERVASI KEAKTIFAN MEMPRODUKSI TEKS EKSPOSISI SECARA LISAN SISWA KELAS $X$ SMAN 2 BANYUASIN 1}

\begin{tabular}{|c|l|c|c|}
\hline NO & Tindakan Persiklus & $\begin{array}{c}\text { Persentase } \\
\text { Peningkatan }\end{array}$ & Peningkatan \\
\hline 1 & Tindakan Siklus I & $50 \%$ & - \\
\hline 2 & Tindakan Siklus II & $90 \%$ & $40 \%$ \\
\hline
\end{tabular}

Dilihat dari peningkatan dari siklus I secara umum baru mencapai $50 \%$ hanya belum mencapai target keaktifan siswa yang diinginkan yaitu $85 \%$, dan dilihat dari siklus II persentase peningkatan, dan siklus II persentase peningkatan menjadi $90 \%$ dan peningkatannya dari siklus I sebesar 40\%.berdasarkan tabel di atas, dapat diketahui nilai kemampuan yang di capai oleh siswa pada setiap aspeknya juga mengalami peningkatan.
4. Rekapitulasi Nilai Rata-rata dan

\section{Presentase Keterampilan}

\section{Memproduksi Teks Eksposisi}

Secara Lisan Persiklus Tindakan.

Peningkatan nilai kemampuaan memproduksi teks eksposisi disajikan dalam rekapitulasi tabel berikut ini. Hal ini untuk memudahkan membaca tingkat keberhasilan siswa persiklus.

\section{REKAPITULASI NILAI KEMAMPUAN SISWA MEMPRODUKSI TEKS EKSPOSISI SECARA LISAN KELAS X IPA1 SMAN 2 BANYUASIAN 1}

\begin{tabular}{|l|l|l|l|}
\hline NO & Nama Siswa & Hasil Tindakan Persiklus & Keteranagn \\
\hline
\end{tabular}




\begin{tabular}{|c|c|c|c|c|}
\hline & & Siklus I & Siklus II & \\
\hline 1 & $\mathrm{AB}$ & 65 & 75 & Berhasil \\
\hline 2 & $\mathrm{AD}$ & 45 & 85 & Berhasil \\
\hline 3 & AT & 75 & 85 & Berhasil \\
\hline 4 & $\mathrm{AM}$ & 45 & 75 & Berhasil \\
\hline 5 & $\mathrm{AR}$ & 45 & 65 & Kurang Berhasil \\
\hline 6 & AN & 45 & 75 & Berhasil \\
\hline 7 & AY & 65 & 85 & Berhasil \\
\hline 8 & DK & 65 & 75 & Berhasil \\
\hline 9 & $\mathrm{DN}$ & 75 & 75 & Berhasil \\
\hline 10 & ES & 75 & 85 & Berhasil \\
\hline 11 & EL & 75 & 75 & Berhasil \\
\hline 12 & FJ & 75 & 75 & Berhasil \\
\hline 13 & JK & 45 & 65 & Kurang Berhasil \\
\hline 14 & JT & 65 & 75 & Berhasil \\
\hline 15 & LM & 45 & 70 & Berhasil \\
\hline 16 & MF & 45 & 75 & Berhasil \\
\hline 17 & MY & 75 & 75 & Berhasil \\
\hline 18 & MD & 45 & 70 & Berhasil \\
\hline 19 & MS & 35 & 75 & Berhasil \\
\hline 20 & ND & 75 & 75 & Berhasil \\
\hline 21 & $\mathrm{NK}$ & 75 & 75 & Berhasil \\
\hline 22 & NM & 75 & 75 & Berhasil \\
\hline 23 & $\mathrm{RN}$ & 55 & 75 & Berhasil \\
\hline 24 & SN & 75 & 75 & Berhasil \\
\hline 25 & ST & 55 & 55 & Kurang Berhasil \\
\hline 26 & SR & 60 & 85 & Berhasil \\
\hline 27 & TS & 45 & 75 & Berhasil \\
\hline 28 & TT & 70 & 80 & Berhasil \\
\hline 29 & WL & 65 & 85 & Berhasil \\
\hline 30 & WY & 65 & 90 & Berhasil \\
\hline \multicolumn{2}{|c|}{ Jumlah Nilai } & 1.890 & 2.305 & \\
\hline \multicolumn{2}{|c|}{ Rata-rata } & 62,33 & 76,83 & \\
\hline
\end{tabular}




\begin{tabular}{|l|c|c|c|}
\hline Kemampuan Siswa & & & \\
\hline $\begin{array}{l}\text { Jumlah Siswa } \\
\text { Mencapai KKM }\end{array}$ & 14 & 27 & 27 \\
\hline $\begin{array}{l}\text { Presentase } \\
\text { Kemampuan Siswa }\end{array}$ & $46,47 \%$ & $90 \%$ & $90 \%$ \\
\hline
\end{tabular}

Berdasarkan pengolahan data di atas, hasil dari penelitian siklus I masih rendah, atau belum bisa mencapai Kriteria Ketuntasan Minimal (KKM). Nilai rata-rata kemampuan siswa memproduksi teks eksposisi secara lisan baru mencapai 62,33 yang baru dicapai oleh 14 siswa atau $(46,67 \%)$ sedangkan nilai Kriteria Ketuntasan Minimal (KKM) yang harus dicapai minimal 26 siswa atau $85,00 \%$ dari jumlah siswa. Dan rekapitulasi pada tindakan siklus II mengalami peningkatan menjadi 76,83\%. Persentase kemampuan siklus II mengalami peningkatan menjadi 27 siswa atau 90\%. Berdasarkan tabel 4.10 di atas, dapat diketahui nilai kemampuan yang dicapai oleh siswa pada setiap aspeknya juga mengalami peningkatan.

\section{PRESENTASE NILAI RATA-RATA TES KEMAMPUAN MEMPRODUKSI TEKS EKSPOSISI SECARA LISAN SISWA KELAS X IPA1 SAMN 2 BANYUASIN 1}

\begin{tabular}{|c|c|c|c|c|}
\hline $\begin{array}{c}\text { Pelaksanaan } \\
\text { Tindakan }\end{array}$ & $\begin{array}{l}\text { Sesuai Syarat } \\
\text { Memproduksi } \\
\text { Teks Eksposisi }\end{array}$ & $\begin{array}{l}\text { Pemilihan } \\
\text { Kata Sesuai } \\
\text { teks }\end{array}$ & $\begin{array}{l}\text { Kesesuaian } \\
\text { dengan Siswa }\end{array}$ & Jumlah \\
\hline Tindakan Siklus I & 21,33 & 21,33 & 20,33 & 62,33 \\
\hline Tindakan Siklus II & 26,16 & 25,33 & 25,16 & 76,83 \\
\hline
\end{tabular}

Berdasarkan siklus I hasil rekapitulasi sesuaai syarat memproduksi teks ekposisi siawa 21,33, pemilihan kata sesuai teks 21,33 dan kesesuaian dengan siswa 20,33 dengan jumlah 62,33 , selanjutnya siklus II dilihat tabel 4.11 hasil rekapitulasi sesuaai syarat memproduksi teks ekposisi siawa 26,33, pemilihan kata sesuai teks 25,33 dan kesesuaian dengan siswa 25,16 , dengan jumlah 76,83.jadi dilihat dari tabel 4.11 persentase rata-rata tes kemampuan memproduksi teks eksposisi secara lisan ada peningkatan $14,50 \%$. 


\begin{tabular}{|c|c|c|c|}
\hline No & Tindakan Persiklus & Presentase Peningkatan & Peningkatan \\
\hline 1 & Tindakan Siklus I & $62,33 \%$ & - \\
\hline 2 & Tindakan Siklus II & $76,83 \%$ & $14,50 \%$ \\
\hline
\end{tabular}

Berdasarkan presentase tes kemampuan memproduksi teks eksposisi pada tabel 4.12 yaitu analisis siklus I, 62,33 selanjutnya pada siklus II jumlah presentase peningkatan kemampuan memproduksi teks eksposisi secara lisan berjumlah $76.83 \%$ peningkatannya sebesar $14.50 \%$. keberhasilan siswa tersebut, pada siklus II siswa sudah mencapai kriteria yang ditentukan oleh Kriteria Ketuntasan Minimal (KKM) yaitu 70. Yang sudah dicapai oleh siswa $85 \%$.

Berdasarkan presentase tes kemampuan memproduksi teks eksposisi pada tabel 4.12 di atas, maka bisa dideskrisikan bahwa penelitian tindakan yang dilakukan oleh peneliti mengalami peningkatan $\quad 10,83 \%$. Jumlah peningkatan ini jika dibandingkan dengan hasil penelitian yang relevan terdahulu.

\section{SIMPULAN}

Berdasarkan data analisis, dan pembahasan dalam penelitian ini yang telah diuraikan pada bab sebelumnya, maka penulis mengambil kesimpulan pada siklus I aspek pengamatan proses masih belum maksimal. Namun, pada siklus II setiap aspek pengamatan proses mengalami peningkatan dan predikat aspek tahap think (berpikir) kesungguhan peserta didik saat mengamati media video atau teks mengalami peningkatan dalam segi perolehan skor keseluruhan. Aspek tahap think (berpikir) keaktifan peserta didik ketika kegiatan tanya-jawab mengalami kenaikan dalam segi perolehan skor keseluruhan serta predikat dari siklus I ke siklus II. Aspek tahap think (berpikir) keantusiasan peserta didik saat mengumpulkan informasi juga sama dengan aspek pertama, mengalami peningkatan dalam segi perolehan skor keseluruhan. Begitu juga dengan aspek tahap pair (berpasangan) kekompakan peserta didik saat mengasosiasi mengalami kenaikan dari segi perolehan skor keseluruhan dari siklus I ke siklus II. Aspek yang diamati terakhir mengalami peningkatan adalah aspek tahap share (mengomunikasikan) kepercayaan diri peserta didik saat mengomunikasikan ada peningkatan. Rata-rata peningkatan hasil pengamatan proses pembelajaran 
dari siklus I ke siklus II meningkat menjadi dua puluh tujuh siswa atau sembilan puluh persen $(90 \%)$ hal ini terjadi peningkatan sebesar empat puluh tiga koma tiga puluh tiga persen $(43,33 \%)$.

\section{REFERENSI}

Afandi, R. (2013). Implementasi Kurikulum 2013 dalam mempersiapkan sumber daya manusia Indonesia Menghadapi” Masyarakat Ekonomi Asean Economic Community) Pada 2015. In Prosiding Seminar Nasional Pendidikan:

Tema'Implementasi

Kurikulum.

(diakses 03 Juli 2020).

Arikunto, Suharsimi. 2014. Penelitian Tindakan Kelas. Jakarta: Bumi Aksara

Daryanto. 2014. Penelitian Tindakan Kelas dan Penelitian Tindakan Sekolah Beserta ContohContohnya. Yogyakarta: Gava Media.

Ekawarna. 2011. Penelitian Tindakan Kelas. Jakarta: Gaung Persada.

Houtman. 2019.Pedoman Penulisan Tesis Program Pascasarjana. Universitas
PGRI; Palembang.

Kementerian. Pendidikan dan Kebudayaan Republik Indonesia, 2017. Bahasa Indonesia SMA Kelas X. Jakarta: Pusat Kurikulum dan Perbukuan, Balitbang, Kemendikbud.

Kosasi,E. 2017. Jenis-Jenis Teks dalam Mata Pelajaran Bahasa Indonesia SMA. Bandung; Yrama Widiya.

Mulyadi, Yadi.2016.Bahasa Indonesia Untuk Siswa SMA Kelas X. Bandung:Yrama Widya.

Ruhcitra. 2008. "Pembelajaran

Kolaboratif."

http://ruhcitra.wordpress.com/20

08/08/09/pembelajaran-

kolaboratif/

(diakses 01 Juli 2020).

Saddhono, Kundharu. 2014

Pembelajaran Keterampilan Berbahasa Indoensia Teori dan Aplikasi. Yogyakarta: Graha Ilmu.

Tarigan, Henry Guntur. 2015. Bebicara Sebagai Suatu Keterampilan Berbahasa.Bandung: Angkasa.

Uno,Hamzah.2014. Menjadi Peneliti PTK yang Profesional. Jakarta: Bumi

Aksara. 